\title{
Kautilya's The Arthashastra: A Marxist and Psychoanalytical Reading of Select Chapters in Book I.
}

\author{
G.S. Aravind \\ Research Associate, School of Social Sciences and Languages, VIT University, Vellore, India \\ Email: gsaravindgs@gmail.com

\section{Dr. Laxmi Dhar Dwivedi}

Associate Professor, School of Social Sciences and Languages, VIT University, Vellore, India

\author{
Doi:10.5901/mjss.2015.v6n6s2p678
}

\begin{abstract}
In the proposed paper, we attempt to make use of some highly influential theories such as Marxist theory and Psychoanalytical Theory to analyze the pioneering work on statecraft and political psychology namely The Arthashastra by Kautilya (370-283BC) a classical discourse, which is highly relevant even today. For instance, the paper uses the concepts propounded by Louis Althusser and Antonio Gramci. Althusser's concept of 'state power' and 'state control' along with Gramci's concept of 'rule' and 'hegemony' is associated with Kautilya's technique of 'demonstrating omniscience' of the king which is described in Book I, chapter X1. Kautilya refers in Book I, chapter IX about 'ambition' and 'lust' as the general methods in tackling clandestine agents for protecting the best interests of the King. Such an idea wouldn't have dawned upon Kautilya unless he makes an intense probe into the fundamental nature of human psyche. This fact becomes even more surprising because it was written in 4th century when there hadn't been any systematic and established body of knowledge on human mind and the unconscious as we have today in the 21 st century.
\end{abstract}

Keywords: Kautilya, The Arthashastra, Marxism, Psychoanalytical.

\section{Introduction}

The Arthashastra by Kautilya is by far one of the finest political and war discourses ever written in prose form. Dating back to $4^{\text {th }}$ Century B.C, it contains tremendous far-sighted psychoanalytical elements embedded in it. Kautilya, is often referred to as a modern-day economist and war strategist in his times. Having belonged to one of the oldest Indian civilizations, he has spelt out clear principles for espionage and stressed the importance of spies. Often compared to Machiavelli's The Prince and Aristotle's Politics, The Arthashastra contains a detailed account of first-hand human experiences.

Kautilya (370 - 283 B.C.) is perhaps by and large considered ruthless in his teaching and writings. His primary focus always center toward achieving many objectives and in this very case, on espionage strategy and the importance of spies. Interestingly, The Arthashastra's Book 1, Chapters IX, XI and XIII deal with the use of spies. They can be appointed for special occasions such as weddings or Throne Ascensions and all major festivals according to him could be utilized as occasions for the purposes of insertion or defection of spies.

Kautilya's The Arthasashtra is commonly referred to as "Science of Politics". He himself clarifies that his treatise is not the origination of science but is based on the similar treatises of the past. Chandragupta Maurya ascended the throne about 321B.C. and during his tenure, the illustrated work of Kautilya appeared. Roughly about 2000 years later, the principles laid out by Kautilya astonishingly sounds relevant even today. The first translations to English from Sanskrit were compiled and published by R Shamasastry in the year 1915.

\section{Methodology}

The methodology followed in the paper involves four key stages. In the first phase we attempt to understand the context of The Arthashastra from Kaultilya's point of view. Critical passages drawn from select chapters in The Arthashastra are taken for analysis.

The second leg of it deals with the comprehension of the treatise from the Marxian context. In the third phase, the 
psychoanalytical elements embedded in the political treatise are analyzed. Criticism theories propounded by famous writers also form the quintessential portion of the article.

The final phase consolidates the important aspects propounded by Kautilya related to defense, war and espionage in Chapters IX, XI and XIII in the light of instances that have dominated both the distant and recent past. Popular literary works including novels and movies are taken into consideration to assuage this effect.

\section{Demonstrating Association with God}

In chapter XI of The Arthashastra, Kautilya discusses an invaluable method of warfare, which he terms as 'psychological warfare'. It is one of the many methods of warfare described in the book. It implies that at times, one could conquer much more by controlling people's minds than their physical body using physical force or with the help of an army or judicial system.

It is more powerful and guarantees the allegiance of subjects in a better way, but to make this happen, one needs subtler tactics. According to Kautilya, 'Demonstrating Association with God' is one of the best methods to use in this context. In this section we try to interpret this method with the help of Marxian concepts of 'ideology' and 'hegemony'.

\section{4. 'Ideology' and 'Hegemony' - Fundamental Principles of Marxism}

Marxist criticism suggests that all cultural forms, be it films, books, music or an afternoon soap opera try to ensure that the dominant classes in a society remain dominant. This is done by a mechanism called representation, by which the reader obtains a particular message (only 'the' particular message) that is intended by the author. For achieving the same, reality is sometimes masked, altered and customized to suit the agenda. For instance, let us consider the hugely successful Hollywood movies like Independence Day, Armageddon and Air Force One which projects America as the savior of the world and a country which every other nation turns to in moments of crisis. In the post cold war era when only one superpower remained, American films depicted themselves as all-powerful and this is a fine exemplification of such representation.

At the same time, it is also true that 'resistance literature' in every culture has made a counter attack on such kind of representations- such as working class poetry, anti - colonial writings or women narratives - but the body of such narratives is so small that it doesn't make any significant impact compared to the vast impact of its opponent. The role of Marxist criticism thus becomes active when certain works of art consciously twist the reality for the capitalist and politically dominant class to maintain power and money. At this juncture it intervenes to untangle the twist and reveal the truth.

This 'twist of reality' can also be called by another name - 'Ideology ${ }^{1}$.' It is an instrument of power, which uses all kinds of cultural practices such as writings, speeches, beliefs and opinions to suggest the 'naturalness' of a particular condition. In this context it is the political domination of the upper class.

"Ideology enables the dominant classes to reinforce their power over the oppressed and marginalized classes because ideology serves as a system of beliefs that naturalizes the unequal power relations, and leads the oppressed to accept it as natural, as given and as self- evident and therefore beyond questioning"

- Nayar, Pramod K (2014) (p 131)

Italian thinker Antonio Gramci introduced and popularized another concept named 'Hegemony' ${ }^{2}$ which is akin to the earlier mentioned Ideology. It contains ideology and something more. It refers to the process through which the upper class or dominant strata maintain dominance through similar methods of ideology but with an exception that it is done with the consent of the people. For instance, the first world nations need markets to sell their products. In order to achieve this they propose trade agreements to third world nations and make them believe that it is mutually beneficial. The gullible third world nations believe in their so called theory of 'free trade' and 'sanction of agreement' whereas in reality, it is just another scheme of the first world nations to expand their markets. Thus they achieve their goal through consent than coercion.

\footnotetext{
${ }^{1}$ It is a mode of misrecognizing the true nature of our material lives and social roles when we consume a cultural artifact. It is a system of ideas, values, beliefs that we live by, through which we perceive the world. Nayar, Pramod. K. Contemporary Literary and Cultural Theory (2014). pp -130.

2 It is the domination of particular sections of society by the powerful classes not necessarily through threats of violence or the law but by winning their consent to be governed and dominated. Ibid.
} 


\section{5. 'Ideology' and 'Hegemony' in Kautilya's The Arthashastra}

Back at a time in $4^{\text {th }}$ century $\mathrm{BC}$, a King would have been a much more terrifying and powerful figure than today for his subjects, that he could elicit any level of obedience from them without an iota of protest. Their fear is the instrument through which he maintains his dominance. However it has its shortcomings too. Since power is the deciding factor here, the King would get into trouble when someone more powerful comes into the arena. It would naturally jeopardize his position. This is a very critical point where the King must come out with a better strategy, which would more powerfully elicit the obedience of his subjects than by using physical power or threatening them. Here comes the genius of Kautilya as he comes up with a new tactic to reserve the King's position. It is exemplified in chapter XI of The Arthashastra where he talks about maintaining the King's dominance through demonstrating association with God. He says,

"The conqueror shall make gullible people believe that he is in direct contact with gods by various tricks" - Rangarajan. L.N. (1992), (p 689)

Here Kautilya discovers a mightier tool to hold the King in the supreme position than anything else. With the help of magicians, soothsayers and such men, the King would perform various tricks in front of his subjects. This would surprise the gullible subjects into thinking that he could perform all this because he is closer to God than the common lot. Thus the King is canonized from being a mere ruler to that of an agent of God on earth. This makes the subjects more content and they would believe that their King is the best person to rule them and that they would lead peaceful and prosperous lives hereafter. The core is now shifted from fear to God. Since God is the considered supreme, the King's feigned allegiance with God has now made him more powerful than any other ruler. Thus he easily begins to control them through their mind and not physical body.

The soothsayers, readers of omens, astrologers, reciters of Puranas, intuitionists and clandestine agents who helped the King to perform these tricks would then propagate this new image of the King through the length and breadth of the country by various means such as stories, folk songs etc. They would interpret events as omens like the cawing of craws, animal noises, bird noises and appearance of meteors as signs of impending success of the King and defeat of the enemy. This enables the people to see him in a new light. They slowly begin to love and worship him. They would trust him completely that he is now God's man and that he would never exploit them or do anything bad to them. Whatever he does would then on be deemed good for the country. Any revolt against him would be considered a rebellion against God himself. They would advertise the King's renewed image also in the enemy's territory and forge stories of the appearance of Gods and receiving army and wealth from divine sources. In a nutshell, no one would even dare to think about revolt for the love and fear of the 'Wrath of God'. These details provide a clear indication of how The Arthashastra makes use of the principles of 'ideology' and 'hegemony'. Rather than proclaiming directly that the King must be obeyed and respected, the idea is unconsciously instilled into the minds of the subjects through different means.

In the modern era the help of various cultural artifacts such as films, television and music does the same but in the $2^{\text {nd }}$ century $A D$ the help of soothsayers, saints and such men who mingle with the common men and are highly influential among them does it. It thus directly affects the cultural practices of the people. It finds a way into their belief systems and adds strength to the already existing belief system of God, his supremacy and benevolence. Thus, the new ideology of linking the King with God is an extension of an earlier established notion. Since the bedrock is strong, it becomes easy for the dominant class to sow their seeds more precisely. Nevertheless, this method succeeds in using ideology more by consent than coercion.

\section{Marxist tenet of 'Naturalizing Dominance' in The Arthashastra}

Another important tenet of Marxist ${ }^{3}$ criticism is to expose how the dominant classes persuade the working classes to believe that the present social condition is natural, benevolent and ultimately beneficial to them.

In The Arthashastra, when Kautilya utilizes the good name of saints and soothsayers to vouch for the King by emphasizing that he stands for protecting the best interests of the nation and their God, he is unconsciously persuading the gullible subjects to believe that the present condition is the best they could ever dream of.

They would ultimately take it for granted that by being law-abiding citizens of the benevolent King; it would be ultimately beneficial to them. Through this endeavor the King can ensure unquestioned supremacy inside his kingdom.

${ }^{3} \mathrm{~A}$ theory locates all forms of art within existing social conditions of economics and politics...It pays attention to the modes through which literature and art actively maintain power relations at the cost of the poor. Ibid. p 121. 
Marxist critics regard 'ideology' and 'hegemony' as tools for oppression and exploitation of the working class or the lower strata of society by the upper class primarily for wealth and power. Therefore, the work of a Marxist critic is to unearth such propaganda based representations in all kinds of cultural practices so as to warn the generation of such dangers.

Hence it would be wise to add that our attempt is only to apply Marxian theories in this classical text but never to assert that all these techniques by Kautilya had the sole agenda to exploit the people and to keep them in ignorance. Rather Kautilya thought that for the smooth functioning of a nation, the King and his subjects must join hands and cooperate. In order to achieve this, people must trust him. All these above-mentioned strategies aimed at building that trust. Kautilya says,

"In the happiness of his subjects lies the King's happiness; in their welfare, his welfare. He shall not consider as good only that which pleases him but treat as beneficial to him whatever pleases his subjects"

Rangarajan. L.N. (1992) \{1.19.34\}

\section{Foucault's 'Panopticon' and 'Demonstrating Omniscience'}

Kautilya's The Arthashastra details yet another method of eliciting obedience from his subjects and he calls it the method as 'Demonstrating Omniscience'. It comes under the broad spectrum of psychological warfare. This is a very tactful method where the King makes an impression among the public that he knows everything, that his presence is pervasive. He achieves the same with the help of spies secretly appointed by him. They are spread in all departments across the country. They could be saints, soothsayers and even homemakers.

"He suggests using spies and operatives who are either religious leaders or disguised as such or part of such institutions that most closely match the beliefs and habits of these discontent citizens".

- Sunny Singh, (2013). Blogging The Arthashastra.

The King shall demonstrate his pervasive knowledge by many ways. He would let his chiefs know that he is aware of their domestic affairs and secret activities. Sometimes, he would even reveal knowledge about foreign countries before it becomes public, having got secret sealed information through homing pigeons. When the King projects his pervasive knowledge like this, everyone would be intimidated to plot against him because they don't know whether they are being watched at that moment. They are always under constant threat of being watched. George Orwell's novel 1984(1949) captures this predicament vividly. It's story occurs in the state of Oceania, which is in a state of perpetual war. The people of this state are under constant surveillance as hoardings that say, "Big Brother is Watching You", cover the whole city and hence they lack any sense of freedom. In order to assure good behavior from his officers Kautilya also employs a similar method.

This can be compared to Michel Foucault's 'Panopticon'4. Jeremy Bentham invents panoptic prison in mid $19^{\text {th }}$ century. It is a 'tiered prison arrangement' where a single guard can observe all the prisoners from an advantageous vantage point positioned at the centre, unseen by the prisoners. The whole mechanism is done by a powerful and sophisticated internal coercion that would work without exerting any physical power or violent methods but the prisoners can be effectively controlled. This happens because they believe they are under constant surveillance, as the guard located at the center cannot be seen by them. This is exactly what the King is advised to do in The Arthashastra by which he could guarantee the best support from his officers and subjects.

\section{Psychologies and The Arthashastra}

In the world of espionage, the science of human behavior takes the center-stage and therefore demands a deeper psychoanalytical ${ }^{5}$ approach. The focal point of contention is heavily rested upon many facets of human action and behavior. And it becomes imminent to decode those actions involving human emotions and therefore psychoanalytical introspection becomes mandatory.

\footnotetext{
4 It is a design of a circular prison conceived by the eighteenth century utilitarian Jeremy Bentham: the design consisted of tiered ranks of cells which could all be surveyed by a single warder positioned at the Centre of circle. Barry, Peter. Beginning Theory: An Introduction to Literary and Cultural Theory. (2002). p 176.

${ }^{5}$ It explores the language of the unconscious, of the repressed and the hidden as embodied in literary or cultural texts such as art or fiction. Ibid. $p 64$.
} 
The work significantly portrays the importance of values and habits. In the world of espionage Kautilya deals quite extensively on anger, lust, greed, fear, affection and flattery. Although, most aspects are ruthless in their nature, Kautilya is very clear in military principles that his treatise is for strategic and tactical gains and hence important values such as morality and honesty do not gain prominence.

Chapter IX.i. of The Arthashastra deals with covert operations. It deals with the creation of secret service with spies, secret agents and specialists such as assassins. This is a task of high priority for the King and hence, it was created with meticulous care. An attempt to understand the key strategy behind the process of covert operations would reveal that, in general, the methods play on the weaknesses of men, particularly 'ambition' and 'lust'.

Only someone with an in depth insight on human psychology could scheme such a plan. This is clearly visible in The Arthashastra. According to Sigmund Freud, 'Id'6, 'Ego'7 and 'Super Ego'8 are three parts of the structure of human psyche. Id refers to the animalistic instincts in a person and super ego denotes the highly developed moralizing code. The ego comes in between these two as a balancing force.

For a person to work perfectly, all the three parts must come together in the right proportion and needs to be balanced. In most cases, super ego won't be very strong and that is whom we call gullible people.

'Ambition' comes as a part of Id. In normal conditions one would subdue one's ambition and would live the life of reality but if they are slightly persuaded on that line, they would easily fall prey because for a person whose super ego part is not active, Id can quickly take over and they would fall prey to the offers made by the King.

Similarly, 'Iust' is also a part of id. Freud calls it 'libido' 9 which in other words is the sexual desire of a person, which is very natural, but a lot of religious, moral and social factors could affect it. The King materializes on this aspect and exploits the person's libido to make him do whatever he wants knowing well that it is a person's weakness.

It is surprising to find that Kautilya could frame such a strategy at a time when not many studies were undertaken in human psychology as today. This vividly throws light into his knowledge of human psyche.

\section{Key Findings}

Some of the important findings of this study are furnished below.

- Kautilya's The Arthashastra, the classical text of political statecraft, proves to have embedded in it certain key notions that are closely related to the immensely influential 20th century theories of Marxism and Psychoanalysis.

- The paper shows the effective utilization of the concept of 'ideology 'and 'hegemony', later proposed by Marxist criticism for the king to rule over his subjects with greater ease and control over them.

- This is done by developing a pseudo trust in the subject's mind about the prowess of the king with the help of soothsayers, readers of omens, astrologers and declaimers of puranas. This ancient practice is similar to the construction of 'ideology', which is still a part of politics even though it is achieved by different ways.

- The Marxist tenet of 'naturalizing dominance', the tact of the ruler to make his subjects believe that their present condition is an ideal one so that they remain content without a potential threat of revolution, is found in The Arthashastra even though the text was written centuries before. This throws light into how matured a genius Kautilya was and also that the art of statecraft share many similarities at all points of time.

- 'Demonstrating Omniscience', which is a key technique used by Kautilya in is psychological warfare is found akin to the theory of 'Panoptic State' put forward by Michel Foucault. Both the concepts tries to warn the subjects that the ruler knows and sees everything and eluding his eyes is just a myth. This induces a dreadful feeling in the mind of the subjects if they plot anything secretively against the authority and hence elicits obedience.

- An important aim of Marxist criticism is to make people aware of how they are made to believe by the authorities that their present condition is natural and benevolent for them. Kautilya in The Arthashastra advocated the same tactic used by present day governments too with the help of soothsayers and saints, which beckons the application of Marxist tenets in the text.

\footnotetext{
${ }^{6}$ It denotes area of instincts, dreams, desires and all that does not come to the fore I our consciousness. This is the unconsciousness. Ibid. $p 65$.

7 It is the conscious mind, which we work with, use and are most aware of. It mediates between the unconscious id and the super ego. It is the source of our decision-making and our rational thought. Ibid.

8 It is our conscience. It is drawn from social settings and cultural codes and influences the way the conscious works. Ibid.

${ }^{9}$ Sexuality is the primary drive in our subjectivity according to Freud. Ibid.
} 
- $\quad$ The paper also focuses on Kautilya's in-depth knowledge of human psychology. The tactics used by him for covert operations, especially, which includes spies, is found to have made use of concepts that sound similar to the modern day psychoanalytical concepts of id, ego, super ego and libido.

- Finally, this paper, along with identifying Kautilya's principles with Marxism, would also like to underscore the fact that Kautilya proposed these methods not with any ulterior motive but for the smooth functioning of the government. He ultimately believed that the happiness of the King lies in the happiness of his subjects.

\section{Conclusion}

In this paper, we have attempted to read this monumental work of political statecraft in the light of certain selected concepts in Marxist (ideology, hegemony, state power, state control and panoptic state) and Psychoanalytic theories (id, ego, superego and libido).

'Ideology' and 'Hegemony' are concepts put forward by the Marxist critics. It is founded on the idea that the subjects could be controlled more effectively with other methods than with force. If their minds and thinking can be controlled, it becomes much easier for the king to rule as he would have an obedient population without any potential threat of revolution. The paper describes the idea in detail and how it is achieved in Kautilya's The Arthashastra. Another way of controlling them is to establish a notion among the subjects that the King knows everything and that any secretive attempts for a coup d'état would only result in decapitation. This is compared with Michel Foucault's concept of 'Panoptic State'. The Panoptic State is a tiered prison in a circular arrangement where a single warden can control all the inmates in the prison making use of the advantage of his shrewdly designed vantage point. This assures the good conduct of prisoners, that too by no use of force because the prisoners cannot understand whether they are being watched or who is being watched at a particular time. In Kautilya's ideal state, the king shares a position similar to that of the warden's role.

Along with Marxist criticism, certain important tenets of psychoanalytic criticism are also woven into the paper. Though no theories as such were formulated on the mysterious human psyche during the era of composition of The Arthashastra, a close reading of the text would surprise a reader that many of the techniques used by Kautilya to woo people of importance of the enemy state can be found akin to the modern theories of psychoanalysis. The influence of the concept 'id' and libido is explored in detail in the concerned section.

The chapters dealing with the espionage strategy and the use of spies concerning human behavior are heavily debated on the lines of human excellence. Kautilya clearly makes a distinction between achieving objectives and foregoing human values directed toward a larger cause. Toward achieving larger causes, Kautilya chooses consistently to establish a parallel consensus between the minds of the individual and achieving objective. And the role of the spies are heavily relied upon to negate wars and to avoid the casualties. However ruthless in his ideology, he is considered to be a true realpolitik.

This, in modern day parlance could perhaps be referred to as clandestine operations; assassinations could be referred to as the black operations. These characteristics and strategies involve deep human intellect and require consistent patience to have them established. The discourse also finally depicts accurate endeavor of human conditions and reiterates the importance of survival, which makes Kautilya's The Arthashastra one of the best political discourses ever written with psychological and Marxist elements embedded in them.

\section{References}

Barry, Peter. (2011). Beginning Theory: An Introduction to Literary and Cultural Theory. New Delhi: Viva Books. Nayar K, Pramod. (2014). Contemporary Literary and Cultural Theory. Delhi: Dorling Kindersley.

Orwell, George. (2012). 1984. Maanu Graphic Publishers. Print. Rangarajan. L.N. (1992). The Arthashastra. Penguin Books Ltd India (pp. 689-693), ISBN 9780140446083. Print.

Selden, Raman. Widdowson, Peter. Brooker, Peter. (2005). A Reader's Guide to Contemporary Literary Theory. Great Britan: Pearson Longman.

Singh, Sunny. (2013). Bloggingthearthashastra.blogspot.in. Book I. Chapter XIII. 